\title{
The Embodied Testimony of Domitila Chungara in The Courage of the People (Jorge Sanjinés, 1971)
}

\author{
ISABEL SEGUÍ
}

\begin{abstract}
Awarded in Europe but censored in Bolivia during thirteen years, The Courage of the People (Jorge Sanjinés, Bolivia, 1971) is an outstanding example of Latin American collaborative political cinema. The film is an account of the massacre of St John's eve in the Bolivian mining settlement of Siglo XX in 1967. But it also situates its background, through the mise-en-scène of representative community members' life stories. Domitila Chungara was one of the characters selected to represent the collective; in her case, the organized housewives.

This article analyses the range of testimonial bodily expressions captured in Domitila Chungara's participation in the film: her fighting, maternal and suffering bodies. This performance constitutes her first public testimony that, remarkably, is a play-acting testimonio as opposed to the more common transcribed oral accounts that constitute this genre. The self-representation of Chungara and her comrades in the film breaks down the wall of silence that surrounded women's body-based political practices in the public sphere and gives value to their body-based political culture, instrumental in understanding Bolivian politics in the last century.
\end{abstract}

Keywords: Domitila Chungara; Ukamau; Jorge Sanjinés; testimonio; Collaborative Cinema; Comité de Amas de Casa de Siglo XX; cine-testimonio

Corporeal experiences are central to women's testimonial discourses in Latin America. Placed in the front line of struggles against oppressive systems that range from their households to the wider social and political structure, Latin American women's bodies are both the subjects and protagonists of their liberation as well as the object of atrocious repression (Bartow 2005; Lagos 2006; Marin 1991; Saporta-Sternbach 1991).

This article analyses the range of testimonial bodily expressions captured in Domitila Chungara's participation in the film The Courage of the People (Jorge Sanjinés, Bolivia, 1971). This docudrama displays the collective re-enactment of the slaughter of St John's Eve by its survivors. ${ }^{1}$ In this film, the social activist

The Bolivian social leader Domitila Barrios (1937-2012) was a member of the housewives' organisation of the mining settlement of Siglo XX. In this article, I use her married name, Domitila Chungara, because it became the name of her public persona.

DOI: https://doi.org/10.12697/IL.2017.22.1.15 
Domitila Chungara and her comrades of the Housewives Committee of the Bolivian mining settlement of Siglo XX represent their very own body-based forms of fighting. Chungara's participation in the film constitutes her first public testimony that, remarkably, is a performance testimonio as opposed to the more common transcribed oral accounts that constitute this genre.

A testimonio makes public the life story of a subject of subaltern origin through a first person account often marked by collective content. This is usually carried out through the mediation of a literate compiler and editor who turns the spoken word into a cultural device with the objective of challenging the official history. As the so-called testimonial studies were mostly born within the literary field, the non-literary aspects and forms of testimonial have been hitherto overlooked. However, any testimonio usually originates from an oral account and, consequently, the testimonial practice by Latin American women has appeared under many formats (documentary and docu-fiction films, radio series, plays, comics...). Rather than a specifically literary genre, the Latin American testimonio is a transmedia cultural expression in its primary nature.

Aside from its format, another contentious issue regarding testimonio is whether or not it could be a form of counter-patriarchal collective writing/ performing. Feminist agenda and practices share many characteristics with the testimonial continental project. Nancy Saporta sums it up by explaining:

\begin{abstract}
[...] both [testimonio and feminism] include theory based on and grounded in the reality of a people who are breaking silences; both include theory for those who envision a future distinct from their past oppression; both use discourse who give voice to many others in the same situation; and both influence and are influenced by people who, with their new consciousness as a political subject, make evident the relationship between the personal and the political in a historic moment when the subject sees herself/themselves as an integral part of the collective process. (Saporta 1991: 92)
\end{abstract}

However, it is highly problematic to define the testimonial practices of Latin American women as feminist expressions because many of their protagonists would not agree with that definition. Domitila Chungara is a case in point: although all her oral teachings were ideologically counter patriarchal and she was a tireless fighter against machismo in both private and public social structures, she nevertheless strongly defined herself as a nonfeminist person throughout her entire life. Her political position was based on her deep distrust of an inter-class alliance between women (formulated by Western middle class women) that feminism represented, prioritising instead strategic alliances based on class interests. This lack of identification with what can be called a 
white feminist agenda, which concluded with the rejection of the term itself, is a common trend in women's groups all over non-Western or non-white spheres.

\section{The Housewives' Committee of Siglo XX}

A clear illustration of these political practices that are both counter-patriarchal and non-feminist, at the same time, are the organised housewives of Bolivia. The visibility of women's struggles in the Bolivian mines began in 1961 when the wives of some mining union leaders imprisoned in the capital of La Paz sought the solidarity of other women of the mines in order to collectively demand the release of their husbands. In response to this call, sixty women marched to La Paz where they went on hunger strike and issued a manifesto calling for the liberation of the detainees, in addition to other economic demands. The strike, supported by other sectors of the Bolivian society, lasted ten days and was triumphant.

When the union leaders were released, the women of Siglo XX decided to constitute themselves as an organization within the union movement. This women's organization's importance grew over time, making it an avant-garde within the labour movement (Greaves 1986: 365). Its political significance was not just within the mining unions; their most renowned achievement was catalysing the end of the dictatorship of Hugo Banzer through another hunger strike in 1977. At that time, after sixteen years of struggle, the women of Siglo XX were invested with a symbolic power capable of mobilizing the entire country.

The Housewives Committee of Siglo XX had two main courses of action. The first was to actively support the organization of the mining unions and their structural claims that would benefit the miners and their families, such as, better wages, medical services or supplies at the company grocery stores. Their second course of action were claims on matters that directly affected women, such as, obtaining jobs for single, widowed or abandoned women and also the alliance with women from other sectors, especially peasants (Viezzer 1979: 82).

However, the journey of these organized and visible women was not easy. They faced all kinds of resistance as a result of their political work. Despite the fact that the struggles of the housewives were not feminist-oriented and were aimed to support the demands of the labour movement, they were regarded with suspicion and fear by all men, from their husbands and union leaders to class enemies, such as the mining corporate class and conservative sectors of the Catholic Church (Nash 1993: 243). The governmental reactions to their actions were also varied, from direct repression of women through arrests, imprisonment, and torture, to indirect repression by firing, blacklisting or exiling their husbands. 
The Embodied Testimony of Domitila Chungara in The Courage of the People

\section{Domitila Chungara's testimonios}

Domitila Chungara was the best-known leader of the Housewives Committee of Siglo XX. When she died on March 13, 2012, the Bolivian government declared three days of official mourning - without cessation of activities - and President Evo Morales offered condolences to the "mining family." Her life was marked by imprisonments, tortures, exile, but also a spectacular political success, making her a symbol of Bolivia's fight for freedom.

Much of her international popularity is due to the written testimonio of her life compiled by Moema Viezzer. This book titled Let Me Speak! Testimony of Domitila a Woman of the Bolivian Mines was published in 1977, however it was not her first testimony. Domitila Chungara - because of her effective communication and the depth of her political message - attracted a variety of intellectual allies in a cascade process. In 1971 she starred in the film The Courage of the People by the Bolivian Ukamau group and directed by Jorge Sanjinés. When the Brazilian filmmaker Helena Solberg saw her performance in Ukamau's film, she sought her participation in the documentary The Double Day (1975) an initiative of the collective International Women's Film Project. Since Solberg intended to release her film during the UN Women's Year Tribunal, to be held in Mexico that year, she invited Chungara to participate in the UN forum. In turn, Mexico's Tribunal was the place where Moema Viezzer met Chungara and proposed her the compilation of her written testimonio.

Furthermore, in 1980, Alfonso Gumucio Dagrón made a documentary for the Centre for Investigation and Promotion of the Peasantry (CIPCA), called Domitila, la Mujer y la Organización (Domitila, the Woman and the Organization). Moreover, the Confederation of Indigenous Peoples of Bolivia (CIDOB) published a popular education booklet with the same name to join the film. This set of popular education materials (film and booklet) based on the life and teachings of Chungara was aimed to the Andean peasant women. The same year the booklet trespassed the border and was republished in Cusco (Peru). Finally, in 1985, David Acebey compiled her second written testimonio ;Aquí también Domitila! (Also here Domitila!) that accounts her experiences from 1976 to 1985, from the hunger strike against Banzer's regime to her return from the exile, including her travels around the world.

Chungara's testimonio was a transmedia cultural and educational product that contributed significantly to the creation of a usable counter-public sphere for organized working class and peasant women. That alternative communicative sphere had been present in Bolivia since the 1950s in various forms including radio, film, poetry, plays, essays, assemblies, rallies, speeches, masses, songs, hunger strikes, demonstrations, dynamite launching, roadblocks, food processing 
or care of children and the elderly. The main objective of Domitila Chungara's testimonio was to contribute to the consolidation of this local circuit of production and reception of educational and awareness raising materials in which these cultural products could be consumed, publicly discussed, rebuilt and improved, as an educational work in progress whose main objective was popular emancipation (Barrios and Viezzer 1978: 234).

\section{The Courage of the People. Embodied filmic testimonio}

Awarded in Europe but censored in Bolivia during thirteen years, The Courage of the People is an outstanding example of collaborative political cinema. After two ground breaking feature films - Ukamau (1966) and Blood of the Condor (1969) - Jorge Sanjinés and the Ukamau group got in touch with the mining unions, a continental political avant-garde. ${ }^{2}$ In 1970 they visited the mining region and under petition of the mining community agreed with the union leaders to re-enact the 1967 slaughter of St John's Eve, when under the regime of Rene Barrientos the army entered the mining settlement of Siglo XX and massacred a very large (although never exactly determined) number of people. The objective of this carnage was to avoid a general meeting of miners, students and factory workers scheduled to discuss what sort of support they were going to give to the guerrilla focus organized by Ernesto Che Guevara in the Bolivian rainforest.

The film, coproduced by the Italian State Television (RAI), was edited in Italy and won Pesaro Film Festival in 1971. In the meantime, there was a military coup in Bolivia by General Hugo Banzer, which sent Jorge Sanjinés to the exile, and made him unable to come back to the country until 1978. The return to democracy for the country after Banzer's regime was fragile and a series of military

2 Ukamau was a cinematic group composed of young middle and upper-class intellectuals from the capital city of Bolivia (La Paz). Its members were the director Jorge Sanjinés, the screenwriter Oscar Soria, the cinematographer Antonio Eguino and the producer Ricardo Rada, but also their wives Consuelo Saavedra, Danielle Caillet and Gladys de Rada, and other friends and family members. Their aim was to make a socially committed cinema, through the denounce of national problems, such as classism and racism. They made together the above mentioned three feature films. After Banzer's coup in 1971, the group split in two due to political and personal disagreements. In consequence, Eguino, Soria, and Rada stayed in Bolivia and continued to make a social cinema. Jorge Sanjinés took a much more radical path, in form and content, becoming an icon of Latin American political cinema. While in the exile, he managed to continue to produce films within the Andean world, with peasant communities in Peru and Ecuador. His best-known film is La Nación Clandestina (The Clandestine Nation), awarded with the first prize at San Sebastian International Film Festival in 1989. 
The Embodied Testimony of Domitila Chungara in The Courage of the People

coups happened in the following years, until 1982, when the democracy came back definitely. In consequence, the film was banned for thirteen years. Only those Bolivians in the exile and some attendants to counted screenings inside the country, knew it. Conversely, in Europe, it became a classic piece of 'third cinema' due to its artistic and political qualities. ${ }^{3}$

Conducted only four years after the events, the filming took the form of a collaborative docudrama that included the participation of the slaughter's survivors and witnesses, who reconstructed the events through creative reenactments that included amazing self representations. It constitutes one of the highest examples of what Sanjinés would later call "cinema with the people". The film is an account of the massacre but also situates its background, through the mise-en-scène of community members' life stories. Domitila Chungara is one of the characters selected to represent the collective; in her case, the organized housewives.

\section{The Fighting Body}

The human body plays a prominent part in The Courage of the People, a story of bodies fighting for survival and bodies perishing by State violence. The scenes featuring the Housewives Committee are divided into three consecutive moments and encompass about $13 \%$ of the film. The sequence is an overpowering demonstration of women's agency. The segment starts with the testimony of Chungara in her domestic sphere. Then, we witness protest actions, followed by an assembly of the Committee. Finally, they perform the strongest form of passive resistance: the hunger strike.

3 Third Cinema is a concept coined by Fernando Solanas and Octavio Getino, which describes three cinematic categories: the first is the mainstream cinema made in Hollywood; the second is the European auteur cinema; and the third cinema is the decolonial cinema produced in the Third World.

4 One of the most important developments of Latin American Film Theory is Jorge Sanjinés' book Teoría y Práctica de un Cine Junto al Pueblo (Theory and practice of a cinema with the people), published by Siglo XXI Editores in 1979. Here Sanjinés states the principles of his cinematic practice, not about the people or for the people, but with them. The active and creative participation of the Andean subaltern classes in the production of this cinema generates a new cinematic language culturally appropriate for them. Hence, the Andean proletarians or peasants become producers and consumers of this cinematic product, at the same time. A new circuit of production, distribution and consumption are created outside the colonised mainstream circuit. In consequence, this cinematic practice becomes a revolutionary anti-imperialist practice. 
SEGUÍ

For Chungara's presentation, the film actually frames her household as the space of nutrition and family care. It is nonetheless a precarious space as putting food on the table is a daily struggle. The men's salary is not enough to maintain the family, forcing women to, in addition to engaging in all care tasks in houses with no running water, seek alternative funding sources such as washing and ironing, or informally selling food or other products on the street. Domitila Chungara, helped by her children, daily prepared salteñas (small meat and vegetable pies) to sell on the streets of Siglo XX. In fact, being a street vendor also helped her to connect with the reality of the mining settlement.

While a documentary scene of domestic activities is shown, what is heard, in contrast, is her voice-over talking about the importance of the women's organization and explaining her leading role among the organized housewives. This scarce minute devoted to the presentation of the character provides the necessary information to jump into the next scene: a direct confrontation of Chungara and her comrades with the head of the grocery store as they demand the correct provision of food and other goods.

One of the most important achievements of the mining unions after the nationalization of the mines was the establishment of food stores owned by the mining company, the so-called pulperías. The miners and their families were entitled to assigned weekly quantities of basic products (meat, rice, flour, oil, sugar), but the reality was that the portions were not enough and the pulperías were constantly short of supplies. The struggle for basic nutrition was a daily problem in Siglo XX and other mines in the country. Therefore, the pulpería was one of the nerve centres for women's political activity.

Helena Solberg's documentary The Double Day shows a scene of the pulpería in full activity, with huge queues of women exchanging vouchers for food. In The Courage of the People, the physical space is the same, but the scene is the reenactment of a confrontation with the manager by the leaders of the housewives. Here the filming community, composed by Ukamau crew and the inhabitants of Siglo XX, trespass the boundaries of documentary and enter the realm of a hybrid cinematic language, the testimonial re-enactment performed by the actual protagonists.

In the subsequent scene, dozens of women are gathered at the door of the pulpería waiting for the results of the negotiation. A group of male miners is also present. Men are portrayed as inactive and faint-hearted, even being accused by women themselves of having a cowardly attitude. The community emerges as a collective protagonist where women lead the scene, and men are represented without agency. This collective portrait is emphasized by the position of the handheld camera that moves from the inside of the scene as a member of the community. The cameraman (Antonio Eguino) is not seeking a privileged 
The Embodied Testimony of Domitila Chungara in The Courage of the People

position for recording. He acts as a participant in the events, striving to do his best, but without visual or auricular privileges. This way of operating the camera is a clear example of the decolonization of the cinematic language implied in the 'cinema with the people' technique (see footnote 4), showing how the director Jorge Sanjinés renounces the hegemonic voice in the narrative.

On the other hand, the traveling and humble location of the camera make us feel inside the action supports our position of witnesses, so we can complete the phenomenon of 'collective anamnesis'. This term, coined by the Argentinian scholar María Aimaretti, means that "the film production can be understood as an aesthetic process of group anamnesis triggered by the structuring presence of certain voice: that of the witness, the survivor, which to appear, hear and be heard, needs of others" (Aimaretti 2012: 5, translation mine).

The third scene featuring the Housewives Committee is a hunger strike. According to Javier Sanjinés, the hunger strike is commonly used by Bolivian women as a non-violent political practice and communicative action, portraying a paradox of fighting undernourishment through radical hunger. But it is also a way of celebrating life using the human body in order to foster solidarity and turning personal concerns into public issues. (Sanjinés 1996: 255). Chungara declared hunger strike throughout her life on numerous occasions, both in isolation and collectively. The most successful example of a hunger strike by the women of Siglo XX occurred in 1977 when a strike launched with five of them in La Paz ended with the overthrow of the dictatorship of General Banzer. Catalan Jesuit Luis Espinal accompanied them on this occasion and this is what he wrote about the experience:

Hunger is a violent experience that makes us understand the courage and anger of the people. When you are hungry, you better understand the urgency of working for justice in the world. [...] The hunger strike as any union praxis, has also helped to radicalize and clarify our ideological attitudes. In front of hunger is not useful the talk learned in books. The hunger strike has radicalised us and has radicalised people who have been in contact with us. It is the best politicisation training we have ever attended. (Espinal in López 1984: 243-244, translation mine.)

These experienced women perform a hunger strike in Ukamau's film. The scene takes place in the little school of Siglo XX. Underneath a portrait of Simon Bolívar, striker women with their children wait and sleep while time passes by. The seventh day, the superintendent of the company intends to undo the strike, trying to convince the women to return home. He first appeals to their duty as mothers and wives by reminding them where they belong 'naturally'. Following this 
SEGUÍ

unsuccessful attempt, he accuses them of being communists and of concealing revolutionary aims in their prosaic demands. Women face him, disobeying his authority and not showing any fear when threatened. The scene ends with the superintendent leaving the school harassed by the women of the Committee, who make him flee by beating rocks in a clearly undefeated (and documentary) attitude.

A remarkable consequence of the filming of a large group of women in a political bodily act of this magnitude is that the female fighting bodies of the housewives are impossible to objectify through representation. Instead, their physical presence makes them counter-hegemonic. Here women are ugly, dirty, strong and brave. Their attributes are those opposed to the desirable attributes of women in mainstream cinema. That is the reason why the psychoanalytic approach is useless for the analysis of this filmic text (and many other manifestations of third cinema). The western scopophilic mechanism breaks apart in front of these non-canonical bodies, which are impossible to objectify either physically or politically.

This series started with Domitila Chungara alone in her private space and ended up with all women together, organized, taking public space, confronting the mining authority without fear. The part of the movie starring them ends there. The following scenes in which they appear are those of the slaughter. In the scenes of the aftermath of the slaughter, Chungara appears leaving Siglo XX on a military truck alongside other detainees and holding her baby daughter. Through the testimonials of other witnesses, we will find out that the journey ahead included several years of traumatic repression.

\section{The Maternal Body}

Between the myriad of topics that address body issues in Latin American women's testimonies, maternal issues are key. From middle-class women to peasants, workers or even guerrilla women, all of them address the topic of motherhood in one moment or another, even though just to deny it, as Rigoberta Menchú does in her testimony (Burgos \&Menchú 1983: 342-350). In this regard, Nancy Saporta notes:

In women's testimonial discourse, it is either having lost their children or imagining for them a social change and political transformation that motivates the act of writing. The text itself becomes the symbol for an act of love: not simply abstract love of one's country, one's race, or one's revolution (although these characteristics are also present) but rather, love for the human being 
The Embodied Testimony of Domitila Chungara in The Courage of the People

to whom them gave life $[\ldots]$ the act of writing itself serves as a tribute to the memory of the dead: what has been silenced is spoken and written. (Saporta 1991: 98)

Domitila Chungara's was a mother of seven, hence maternal issues are constantly present in her testimonios. There, she describes a wide range of these experiences from her imprisonment with a two-year-old baby, to the premature birth of a dead fetus that occurred while in detention after being tortured.

In The Courage of the People, the image of the bodies of the struggling women of Siglo XX has an indexical quality, intended to provide authenticity to the narration. The very presence of the body of Domitila Chungara and her compañeras on screen is a documentary proof of the existence of a group of organized women that act politically despite being silenced. Their cinematic physical evidence is itself a political manifesto.

Moreover, those bodies bear an iconic quality. The multiparous body of Domitila Chungara, her large abdomen that generates life represents how life is generated and maintained in the mines of Bolivia. Women are the major sustainers of life within the mining community - and almost in all human societies due to the international sexual division of labour, which ascribes them the caring role and they play a significant role in this film because they also play a significant role in national politics. June Nash reminds us that in the mining region "the clergy were prompted to counter the women's hunger strike implying that woman's body, as a reproductive vessel, was not her own property to threaten by subjecting it to hunger strikes. This was never asserted in the case of the hunger strikes carried out by men" (Nash 1993: 243).

Every cultural system, including every revolution, displays its own archetype around women's bodies. In the case of the Bolivian revolution of 1952 the ideal role assigned for women was 'revolutionary motherhood', the revolutionary project rhetorically and practically underpinned women's responsibilities in the reproductive sphere and the state was called on to educate them to guarantee their efficiency (Pacino 2015: 63). The strategies developed to meet the expectations towards that model of motherhood such as 'mother's clubs' caused a non-desired effect: the actual empowerment of Bolivian subaltern women. As a result, groups of Bolivian women seized the opportunity of escaping the private sphere - with the legitimate alibi of attending meetings or training - and launched themselves to the public sphere (Pacino 2015: 71). The undeniable importance of women's bodies (carriers of life and culture) in Bolivian national politics has made women's body-based struggles dangerous and subversive, until now. 
SEGUÍ

\section{The Suffering Body}

In Ukamau's film, the last image of Chungara shows her and her daughter arrested in a military truck leaving Siglo XX towards an unknown destination after the massacre. The film's only explanation of the consequences of this detention and Chungara's ordeal in general is an obscure sentence in her presentation, at the very beginning: "I lived through the worst times of barrientismo". The bare facts are that Chungara was imprisoned with her daughter in La Paz, where she was made to believe that the rest of her sons and daughters were also imprisoned in order to blackmail her into giving up their custody. After being released, she suffered a second arrest and, in this case, physical torture. The beatings caused her to lose many teeth - as can be noticed in the film -, wounds, and a premature birth. She delivered the baby, alone and still unconscious, in a dark, humid and filthy cell. Upon awaking, she followed her own umbilical cord and found her little baby boy dead on the floor. She was almost dying, after a birth in those conditions, when finally, a sympathetic soldier helped her to expel the placenta. Afterward, she was taken to a hospital where, under 24-hour surveillance, she slowly recovered from her physical wounds. Directly from the hospital, she went into exile in the Yungas of La Paz.

The Courage of the People details everything leading up to the slaughter, but not the consequences. It is striking that Chungara was willing to re-enact her own role in the film, after the ordeal she suffered as a consequence of her open political position in the events. But the film does not mention it. This information is conveyed through the posterior movie The Double Day by Helena Solberg. This documentary demonstrates that sometimes the gender alliance between middle-class intellectuals and subaltern activists is useful for creating a political storytelling intended for women's liberation. Unlike Sanjinés, Solberg interviews Chungara extensively about the reasons for her detention after the slaughter. Through her directed questions, the Brazilian filmmaker points out the direct relationship between Chungara's political act of speaking out publicly and the subsequent repression. This is a key question that enables Chungara to explain that she was detained after haranguing the crowd against the government during the burial of the victims. Moreover, she affirms that this was her first public speech in front an assembled mob.

Solberg managed to highlight the dangerous consequences, and political importance, of the act of speaking out for a woman leader like Chungara. The detailed testimony of her entire traumatic experience, however, will not happen until she finds the proper listener in 1975. Brazilian Moema Viezzer gave her a trustful space of love, confidence, and comradery, which allowed her to share 
her whole story. Viezzer became the "co-owner of the traumatic event...The listener has to feel the victim's victories, defeats, and silences, know them from within, so that they can assume the form of testimony." (Felman and Laub 1991: 57)

Moreover, in the particular case of Latin American testimonio, the collective implications of the individual act of speaking endow it with a transformative and emancipatory strength unknown in other testimonial contexts, such as those referred by Felman and Laub. In recent works it has been pointed out the need to pay attention to different and decolonized forms of dealing with memory and trauma (Craps 2013), especially those forms coming from those very rich cultural/educational practices developed by subaltern subjects in non-central parts of the world. Probably because Latin American subaltern subjects, who spoke in testimonial forms, were already born and raised in broader traumatic contexts, whose origin goes back to the genocide/epistemicide started by the Spaniards in the $16^{\text {th }}$ century, and continued until $21^{\text {st }}$ century under the disguise of economic globalization. This systemic and chronic subalternisation and marginalization of Latin American people is a traumatic context that prompts testimonio to arise as a collective political tool, and not as an individual psychological therapy. All Chungara's testimonios offer different degrees of depth and had different purposes including healing for herself, for her close community and for the broadened community of Latin American subaltern classes.

\section{Conclusion}

The Courage of the People documents the struggle of the mining settlements and unearths the hidden history of State violence and accuses the perpetrators. Moreover, by opening the participation in the production to organised subjects allows them to self-represent their political praxis. This is especially important in the case of women whose struggles are frequently made invisible by media.

The sequence featuring the Housewives organization in The Courage of the People begins with Domitila Chungara alone in her private space but ends with the collective of women taking the public space. This cinematic testimonio had two outcomes: first, it was an educational and empowering process for the participating women; second, the film was used to raise awareness within other subaltern groups in a transnational counter-public sphere.

A film is always a mediated product, which here results in the hybridization of two epistemes: the one coming from the mental structures and cultural capital of the urban literate members of the Ukamau group and the one coming 
SEGUÍ

from the political practices of the wise illiterate women of the Bolivian mines. This epistemic encounter becomes a loving one, resulting in an amazing filmic testimonio in which a framework of knowledge is not imposed over the other. These works consequently break down the wall of silence that surrounded women's body-based political practices in the public sphere and give value to their body-based political culture, instrumental in understanding Bolivian politics in the last century.

\author{
Isabel Seguí \\ is47@st-andrews.ac.uk \\ 99 North Street \\ St Andrews Fife \\ KY16 9AD Scotland \\ UK
}

\title{
Works Cited
}

Acebey, D., Barrios de Chungara, D. 1985. ¡Aquí también, Domitila!. México: Siglo XXI.

Aimaretti, M. G. 2012. Revivir la experiencia, narrar la masacre, impugnar la Historia : sobre el uso del testimonio en 'El coraje del pueblo' (Grupo Ukamau-Jorge Sanjinés, 1971).- Afuera Estudios de Crítica Cultural, http://www.revistaafuera.com/articulo. php?id=268\&nro=12 (14.04.13).

Barrios, D., Viezzer, M. 1978. Let me Speak! Testimony of Domitila, a Woman of the Bolivian Mines. London: Stage 1.

Bartow, J. R. 2005. Subject to Change. The Lessons of Latin American Women's Testimonio for Truth, Fiction \& Theory. Chapel Hill: University of North Carolina Press.

Burgos, E., Menchú, R. 1983. Me llamo Rigoberta Menchú. Havana: Ediciones Casa de las Américas.

Chungara, D. 1980. La Mujer y la Organización. La Paz: Centro Las Casas.

Craps, S. 2013. Postcolonial Witnessing. Trauma Out of Bounds. Basingstoke (UK), and New York (USA): Palgrave Macmillan.

Felman, S., Laub, D. 1992. Testimony: Crises of Witnessing in Literature, Psychoanalysis, and History. New York: Taylor \& Francis.

Fernández Olmos, M. 1989. Latin american testimonial narrative, or women and the art of listening. - Revista Canadiense De Estudios Hispánicos, 13 (2), 183-195.

Greaves, T. C. 1986. The woman's voice in Andean labor unions. - Urban Anthropology and Studies of Cultural Systems and World Economic Development, 15 (3-4) (09/01), 355-376.

Lagos, M., comp. 2006. Nos hemos forjado así: Al rojo vivo y a puro golpe. Historias del Comité de Amas de Casa de Siglo XX. La Paz: Plural Editores. 
The Embodied Testimony of Domitila Chungara in The Courage of the People

López Vigil, J. I. 1984. Una mina de coraje. Radios mineras de Bolivia. Quito: Aler-Pio XII.

Marin, L. 1991. Speaking Out Together: Testimonials of Latin American Women. Latin American Perspectives 18 (3, Voices of the Voiceless in Testimonial Literature, Part I) (Summer), 51-68.

Nash, J. C. 1993. We Eat the Mines and the Mines Eat Us: Dependency and Exploitation in Bolivian Tin Mines. New York: Columbia University Press.

Pacino, N. L. 2015. Creating Madres Campesinas: Revolutionary Motherhood and the Gendered Politics of Nation Building in 1950s Bolivia. - Journal of Women's History, Vol. 27, No. 1, Spring, 62-87. DOI: 10.1353/jowh.2015.0004.

Saporta-Sternbach, N. 1991. Re-membering the dead: Latin american women's "testimonial" discourse. - Latin American Perspectives, 18 (3, Voices of the Voiceless in Testimonial Literature, Part I) (Summer), 91-102.

Sanjinés, Jorge and Ukamau group. 1979. Teoría y práctica de un cine junto al pueblo. Mexico: Siglo XXI editores.

Sanjinés, Javier. 1990. From Domitila to 'los relocalizados': Testimony and Marginality in Bolivia. - Inti: Revista de literatura hispánica, 32, 138-147.

Sanjinés, Javier. 1996. Beyond Testimonial Discourse: New Popular Trends in Bolivia. G. Gugelberger, ed., The Real Thing. Durham, London: Duke University Press, 254-265.

Viezzer, M., Chungara, D. 1977. Si me permiten hablar. Testimonio de Domitila, una mujer de las minas de Bolivia. México: Siglo XXI.

Viezzer, M., Dietz, J., Tuchman, P. 1979. El Comité de Amas de Casa de Siglo XX: An Organizational Experience of Bolivian Women. - Latin American Perspectives, 6 (3), 80-86. 